\title{
Effects of a Combination of Dietary Restriction and Exercise Training on Myocardial Apoptosis in Male Rats
}

\author{
Hassan Pourrazi ${ }^{1^{*}}$, Afshar Jafari ${ }^{2}$ \\ 1- Assistant Prof, Department of Physical Education, Faculty of Social Sciences, Imam Khomeini International University, Qazvin, Iran. \\ 2- Associate Prof, Department of Exercise Physiology, Faculty of Physical Education and Sport Sciences, Shahid Beheshti University, Tehran, Iran.
}

\section{A B S T RAC T}

Background and Objectives: Apoptosis plays a key role in pathogenesis of various cardiovascular diseases due to loss of terminally differentiated cardiac myocytes. Therefore, the aim of this study was to investigate effects of combined dietary restriction and aerobic training on indices of myocardial apoptosis in male rats.

Materials and Methods: In this study, 32 three-month-old male rats were randomly divided into four major groups: 1) sedentary control (SED), 2)exercise training (EX), 3)diet restriction (DR) and 4)exercise training and diet restriction $(\mathrm{EX}+\mathrm{DR})$. All groups participated in the study for three months. Animals in SED and EX groups were fed ad libitum, while animals in DR and EX+DR groups were given access to 50\% of the control animal diets. Animals in EX and EX+DR groups were involved in a three-month aerobic training program. Rat hearts were removed $48 \mathrm{~h}$ after the last training session. The Bax, Bcl-2 and caspase-3 gene expressions were analyzed using reverse-transcriptase polymerase chain reaction (RT-PCR). Data were analyzed using two-way ANOVA method.

Results: Results showed that the Bax gene expression and Bax/Bcl-2 ratio were significantly lower in trained rats than untrained rats $(\mathrm{P}<0.05)$. Furthermore, Bcl-2 gene expression was significantly higher in $\mathrm{EX}+\mathrm{DR}$ group than other groups $(\mathrm{P}<0.05)$. However, exercise training and dietary restriction did not affect caspase-3 gene expression $(\mathrm{P}>0.05)$.

Conclusions: Overall, it seems that combination of dietary restriction and exercise training results in a significant increase in antiapoptotic Bcl-2 gene expression. However, further studies are needed to show effects of combined dietary restriction and exercise training on apoptosis.

Keywords: Bax, Bcl-2, Caspase-3, Dietary restriction, Exercise training

\section{Introduction}

In recent decades, concerns have raised over rapid prevalence of non-communicable diseases (NCDs) such as diabetes and cardiovascular diseases (CVDs) worldwide. Generally, CVDs are the major causes of disability and premature death in world while substantially increase costs of health care, mortality and morbidity (1). At cellular levels, CVDs are mediated by various mechanisms. Examples include enhanced production of inflammatory cytokines and adhesion molecules, mitochondrial damage and apoptosis (2-4). Numerous studies have shown that cardiomyocyte apoptosis is increased in cardiac diseases or heart failure and is a good marker of poor cardiovascular outcomes $(4,5)$. Wencker et al. have revealed that increasing apoptosis by only $0.023 \%$ in mice cardiomyocytes results in dilated cardiomyopathy after 2-6 months (6). Apoptosis is initiated by the two important pathways of extrinsic Fas receptor-dependent and intrinsic mitochondriamediated apoptotic pathways (7-9). Evidence suggest that intrinsic pathway, including the B-cell leukemia/lymphoma-2 (Bcl-2) family, is critical in modulation of apoptosis (9-11). The Bcl2, an antiapoptotic protein, prevents cytochrome $\mathrm{C}$ release whereas Bax, a pro-apoptotic protein, enhances cytochrome $\mathrm{C}$ release from mitochondria. When cytochrome $\mathrm{C}$ is released from mitochondria into cytosol, caspase 9 protein is activated. Caspase 9 
further activates caspase 3 and executes the apoptotic program $(7-9,12)$. Therefore, researchers are developing technical strategies to protect myocardia against apoptosis and its potential cell injuries. Recently, effects of dietary restriction and exercise training on apoptosis have attracted interests of many researchers. Results of studies demonstrate that calorie or dietary restriction (without malnutrition) may act as an anti-apoptotic factor $(13,14)$. Lin et al. have found that food restriction for maintaining normal weight could promote anti-apoptotic and pro-survival effects on rat heart (5). Unlike results from this study, Patel et al. have shown that caloric restriction shortens lifespan via increases in lipid peroxidation, inflammation and apoptosis in mice (15). However, results of studies on effects of exercise training on apoptosis are controversial. Quindry et al. have reported that exercise training promotes cardioprotection against ischemia reperfusion induced apoptosis and tissue death (10). However, Li et al. have shown that longterm endurance exercise can change cardiac $\mathrm{Bcl}-2$ and Bax mRNA expression and induce cardiac apoptosis via oxidative stress (16). Although effects of exercise training and dietary restriction are commonly studied on apoptosis, interactions between the two interventions on cardiac apoptosis are poorly studied. Furthermore, signaling process of these interventions on apoptosis and cell aging still remains unclear. Therefore, the aim of the current study was to assess interactions between exercise training and dietary restriction on rat myocardial apoptosis.

\section{Materials and Methods}

Animals: An experimental design was employed for this study and all experimental procedures were performed according to the guidelines of Helsinki declaration and approved by the Regional Research Ethics Committee of the Tabriz University of Medical Sciences. Thirty two male Wistar rats (Rattus norvegicus) were purchased from the Pasteur Institute in Tehran, Iran. All rats were housed in pathogen-free conditions at $22 \pm 2{ }^{\circ} \mathrm{C}$, with a relative humidity of 50 $\pm 10 \%$ and a 12-h dark/light cycle. Before the intervention, all rats were fed a regular chow diet and water ad libitum.

Exercise training protocol: After 14 days of acclimation, rats were trained to walk on a motordriven treadmill $\left(0 \%, 10-15 \mathrm{~m} \mathrm{~min}^{-1}, 5-10 \mathrm{~min}^{-1}\right)$ daily for 14 days. At the end of this time period (at the age of 12 weeks), animals were weight matched and randomly divided into four major groups of eight animals as follows: I) sedentary control (SED) II), exercise training (EX), III) diet restriction (DR) and IV) exercise training and diet restriction (EX + DR). Only two groups of EX and EX + DR were involved in an aerobic exercise program on treadmills. The treadmill training program was designed using oxygen costs of treadmill running data (17). Training was consisted of running in the dark cycle for $5 \mathrm{~d} \mathrm{w}^{-1}$ at relative exercise intensity (75-80\% $\left.\mathrm{VO}^{2 \text { peak }}\right)$ for 12 weeks (Table 1). Since handling animals on the treadmill may cause non-exercise stresses, sedentary control animals were trained on the treadmill once a week to familiarize with handling and treadmill environment.

Diet protocol: During the study, SED and EX groups were fed with standard rat chow $3.76 \%$ of fats, $20.96 \%$ of proteins, $52.28 \%$ of carbohydrates, $9.60 \%$ of fibers and $13.40 \%$ of humidity) and water $a d$ libitum. Food restricted groups (DR and EX + DR) received $50 \%$ of the food quantity that was consumed by SED and EX groups (50\% decrease in food intake). Food consumption in SED and EX groups were calculated daily as well as food consumption in food restricted groups. Rats were fed with this dietary regimen for 12 weeks.

Table 1. The exercise training protocol

\begin{tabular}{lcccccccccccc}
\hline & \multicolumn{10}{c}{ Week of training } \\
\cline { 2 - 11 } & 1 & 2 & 3 & 4 & 5 & 6 & 7 & 8 & 9 & 10 & 11 & 12 \\
\hline Exercise duration $\left(\operatorname{min~d}^{-1}\right)$ & 10 & 20 & 35 & 45 & 60 & 60 & 60 & 60 & 60 & 60 & 60 & 60 \\
Treadmill grade (\%) & 15 & 15 & 15 & 15 & 15 & 15 & 15 & 15 & 15 & 15 & 15 & 15 \\
Treadmill speed $\left(\mathrm{m} \mathrm{min}^{-1}\right)$ & 24 & 24 & 25 & 25 & 26 & 27 & 28 & 29 & 30 & 31 & 32 & 33 \\
\hline
\end{tabular}


Tissue removal: All trained animals (EX and EX + DR) were intraperitoneally (IP) anesthetized with ketamine $\left(90 \mathrm{mg} \mathrm{kg}^{-1}\right)$ and xylazine $\left(10 \mathrm{mg} \mathrm{kg}^{-1}\right)$ and sacrificed $48 \mathrm{~h}$ after the last training session. SED and DR group animals were sacrificed at the same time as the trained animals were. The cardiac tissues were carefully removed and rinsed in ice-cold physiological saline solution. The left ventricle was removed and frozen immediately in liquid nitrogen and stored at -70 ${ }^{\circ} \mathrm{C}$ until use.

Isolation of total RNA: Briefly, $50 \mathrm{mg}$ of the left ventricle tissue were homogenized in $1 \mathrm{~mL}$ of lysis buffer. After adding $0.2 \mathrm{~mL}$ of chloroform, vigorous shaking and incubation on ice were carried out on the samples for $5 \mathrm{~min}$. Samples were centrifuged at 13,700 $\mathrm{g}$ for $15 \mathrm{~min}$ at $4{ }^{\circ} \mathrm{C}$. The clear upper phase containing RNA was transferred to a new microtube. An equal volume of cold isopropyl alcohol was added to the microtube and then the microtube was inverted 4-5 times, samples were incubated at $20{ }^{\circ} \mathrm{C}$ for $10 \mathrm{~min}$ before centrifugation at $13,700 \mathrm{~g}$ for $10 \mathrm{~min}$ at $4{ }^{\circ} \mathrm{C}$. The supernatant was discarded and the pellet was washed in $1 \mathrm{~mL}$ of $80 \%$ cold ethanol followed by centrifugation at $13,700 \mathrm{~g}$ for $5 \mathrm{~min}$ at $4{ }^{\circ} \mathrm{C}$. After discarding the supernatant, the pellet was air dried and re-dissolved in diethylpyrocarbonate (DEPC) treated water. Total concentration and purity of the RNA were assessed using Bio-Rad spectrophotometer (Bio-Rad, USA). The RNA integrity was verified using ethidium bromide $(\mathrm{EtBr})$ staining of $28 \mathrm{~S}$ and $18 \mathrm{~S}$ ribosomal RNAs on $1 \%$ agarose gels. After treating RNA with DNase, extracted RNA was stored at $-70{ }^{\circ} \mathrm{C}$ until use.

Complementary DNA (cDNA) synthesis: Briefly, 1 $\mu \mathrm{L}$ of random hexamer primer $\left(2 \mu \mathrm{g} \mu \mathrm{L}^{-1}\right)$ (Fermentas, USA) was added to $2 \mu \mathrm{L}$ of the extracted RNA (100 ng $\mu \mathrm{L}^{-1}$ ) and reached a total volume of $10 \mu \mathrm{L}$ using sufficient amount of DEPC water. Mixture was incubated at $65^{\circ} \mathrm{C}$ for $5 \mathrm{~min}$ and cooled down on ice. Then, $4 \mu \mathrm{L}$ of $5 \times$ reaction buffer, $2 \mu \mathrm{L}$ of $10 \mathrm{mM}$ dNTP mix, $1 \mu \mathrm{L}$ of RiboLock ${ }^{\mathrm{TM}}$ RNase inhibitor (Fermentas, USA) and $1 \mu \mathrm{L}$ of M-MuLV reverse transcriptase were added to the mixture followed by incubations at $25{ }^{\circ} \mathrm{C}$ for $5 \mathrm{~min}, 42^{\circ} \mathrm{C}$ for $50 \mathrm{~min}$ and $72^{\circ} \mathrm{C}$ for $5 \mathrm{~min}$. Finally, a $10-\mu \mathrm{L}$ volume of the cDNA preparation were diluted to $100 \mu \mathrm{L}$ and stored at $-20{ }^{\circ} \mathrm{C}$ until use.

Real-time polymerase chain reaction (real-time PCR) and gene expression analysis: The real-time
PCR was carried out using SYBR ${ }^{\circledR}$ Premix Ex Taq ${ }^{\text {TM }}$ II (Takara, Japan) according to the manufacturer instructions. The mixture included $10 \mu \mathrm{L}$ of SYBR green mix, $1.2 \mu \mathrm{L}$ of cDNA (equivalent to $1 \mathrm{ng}$ of the total RNA with an initial concentration of $100 \mathrm{ng} \mu \mathrm{L}$ $\left.{ }^{1}\right), 0.4 \mu \mathrm{L}$ of each forward and reverse primers in 10 pmol $\mu \mathrm{L}^{-1}$ concentration, and Millipore ${ }^{\circledR}$ water was added to achieve a final volume of $20 \mu \mathrm{L}$. Sequences of the primers are shown in Tables 2. The threshold cycle (CT) was determined manually for each thermal cycling set. The PCR efficiencies for each set of primers were calculated using 10 -fold serial dilutions of cDNA and plots of CT against logarithmic cDNA dilutions based on the efficiency equation of $\mathrm{E}=10^{(-}$ ${ }^{1 / s l o p e)}$. Melting curve analysis was carried out for one cycle at $95{ }^{\circ} \mathrm{C}$ for $5 \mathrm{sec}, 67^{\circ} \mathrm{C}$ for $25 \mathrm{sec}$ and $99{ }^{\circ} \mathrm{C}$ for $0 \mathrm{sec}$ with a ramp rate of $0.1{ }^{\circ} \mathrm{C} \mathrm{s}^{-1}$ and $55^{\circ} \mathrm{C}$ for $30 \mathrm{sec}$. The quantification of mRNA was carried out as a value relative to an internal reference of $\beta$-actin. Gene expression of the samples was calculated in comparison to the controls based on $2^{-\Delta \Delta \mathrm{Ct}}$ method using REST $^{\odot}$ software.

Table 2. Primers used in real-time polymerase chain reaction of gene expression analysis

\begin{tabular}{|c|c|c|}
\hline Gene & Primer sequence & $\begin{array}{l}\text { Product } \\
\text { length }\end{array}$ \\
\hline $\mathrm{Bcl} 2$ & $\begin{array}{l}\text { F: 5'TATATGGCCCCAGCATGCGA3' } \\
\text { R: 5'GGGCAGGTTTGTCGACCTCA3' }\end{array}$ & 136 bp \\
\hline Bax & $\begin{array}{l}\text { F: 5'ATCCAAGACCAGGGTGGCTG3' } \\
\text { R: 5'CACAGTCCAAGGCAGTGGGA3' }\end{array}$ & $150 \mathrm{bp}$ \\
\hline Caspase-3 & $\begin{array}{l}\text { F: 5'GGAGCTTGGAACGGTACGCT3' } \\
\text { R: 5'AGTCCACTGACTTGCTCCCA3' }\end{array}$ & $118 \mathrm{bp}$ \\
\hline$\beta$-actin & $\begin{array}{l}\text { F: 5'CTCTGTGTGGATCGGTGGCT3' } \\
\text { R: 5'GCAGCTCAGTAACAGTCCGC3' }\end{array}$ & $138 \mathrm{bp}$ \\
\hline
\end{tabular}

Statistical analysis: Data were expressed as mean \pm SEM (standard error of the mean). The Shapiro Wilk test was used to verify normal statistic distributions. Furthermore, data were compared to each other using two-way analysis of variance (ANOVA) followed by Tukey test. Associations between the variables were calculated using Pearson's correlation coefficient method. Data were significance when $\mathrm{P}<0.05$. Statistical analyses were carried out using SPSS software v.19 (IBM Analytics, USA). 


\section{Results}

The Shapiro Wilk test showed that data were normally distributed. Table 3 shows effects of dietary restriction and exercise training on characteristics of the animals. Final body and heart weights in dietary restricted groups (DR and EX+DR) were significantly lesser than those in SED and EX groups $(\mathrm{P}<0.05)$. Rats of ad libitum feed increased body weights while DR and EX+DR groups decreased body weights. However, Final body weight in EX group was significantly lower than that in SED group $(\mathrm{P}<0.05)$. The heart to body weight ratio in trained rats was higher than that in untrained rats $(\mathrm{P}<0.05)$. Results showed that food intakes were similar in SED and EX groups with $a d$ libitum feeds $(\mathrm{P}>$.05). The Bax gene expression and $\mathrm{Bax} / \mathrm{Bcl}-2$ ratio were significantly lower in trained rats than SED and DR untrained rats $\left(\mathrm{P}<0.05 ; \mathrm{Eta}^{2}=0.653, \mathrm{Eta}^{2}=\right.$ 0.411). No significant differences were seen between EX and EX+DR groups $(\mathrm{P}>0.05)$. Therefore, the exercise training was the most important factor. The

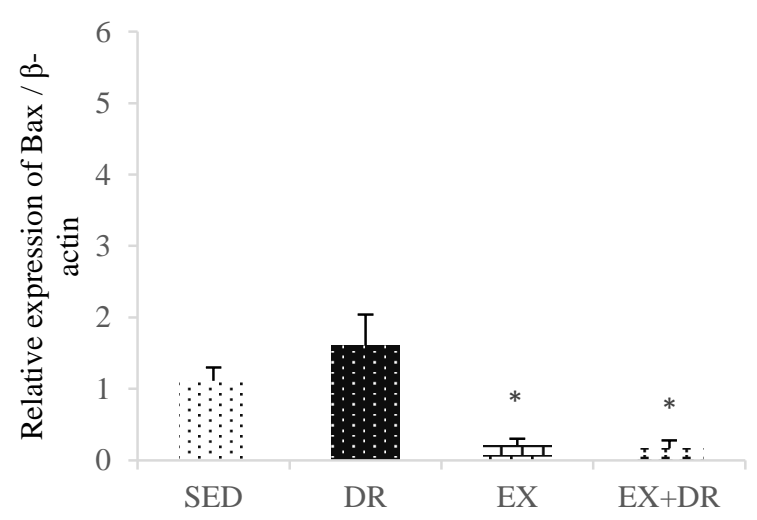

Figure 1. Relative Bax gene expression; SED, sedentary control; $\mathrm{DR}$, dietary restriction; EX, exercise training; EX + DR, exercise training and dietary restriction; ${ }^{*} \mathrm{P}<0.05$ against $\mathrm{SED}$ and $\mathrm{DR}$ groups

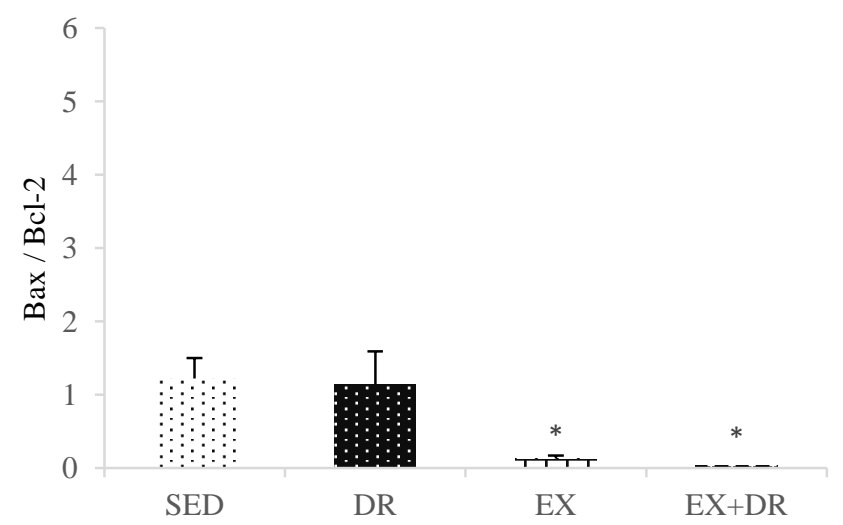

Figure 3. Bax/Bcl-2 ratio; SED, sedentary control; DR, dietary restriction; EX, exercise training; $\mathrm{EX}+\mathrm{DR}$, exercise training and dietary restriction; ${ }^{*} \mathrm{P}<0.05$ against $\mathrm{SED}$ and $\mathrm{DR}$ groups
Bax gene expression and $\mathrm{Bax} / \mathrm{Bcl}-2$ ratio were similar in SED and DR groups $\left(\mathrm{P}>0.05 ; \mathrm{Eta}^{2}=0.0721, \mathrm{Eta}^{2}=0.004\right)$ (Figures 1 and 3). The Bcl-2 gene expression was significantly higher in $\mathrm{EX}+\mathrm{DR}$ group than other groups $\left(\mathrm{P}<0.05 ; \mathrm{Eta}^{2}=0.156\right)$. The Bcl-2 gene expressions were similar in SED, DR and EX groups $(\mathrm{P}>0.05$ ) (Figure 2). In other words, effects of exercise training and dietary restriction alone on Bcl-2 gene expression were not significant. Furthermore, exercise training $\left(\mathrm{Eta}^{2}=0.095\right)$ and dietary restriction $\left(\mathrm{Eta}^{2}=0.079\right)$ did not affect caspase-3 gene expression with results in all groups $(\mathrm{P}>0.05)$ (Figure 4). Results indicated a significant negative correlation between the Bax and $\mathrm{Bcl}-2$ gene expressions $\quad(\mathrm{r}=-0.404 ; \quad \mathrm{P}=0.018)$. However, no significant correlations were seen between the Bax and $\mathrm{Bcl}-2$ gene expressions and the caspase-3 gene expression $(\mathrm{P}>0.05)$.

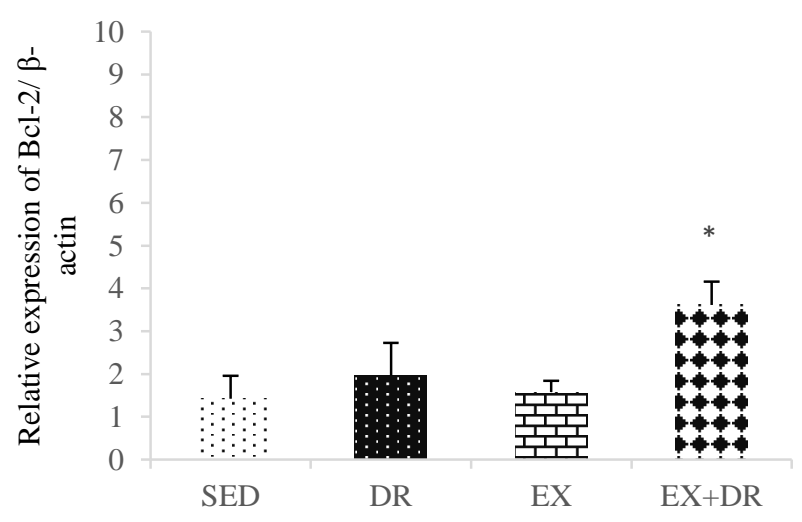

Figure 2. Relative Bcl-2 gene expression; SED, sedentary control; $\mathrm{DR}$, dietary restriction; EX, exercise training; EX + DR, exercise training and dietary restriction; ${ }^{*} \mathrm{P}<0.05$ against all groups

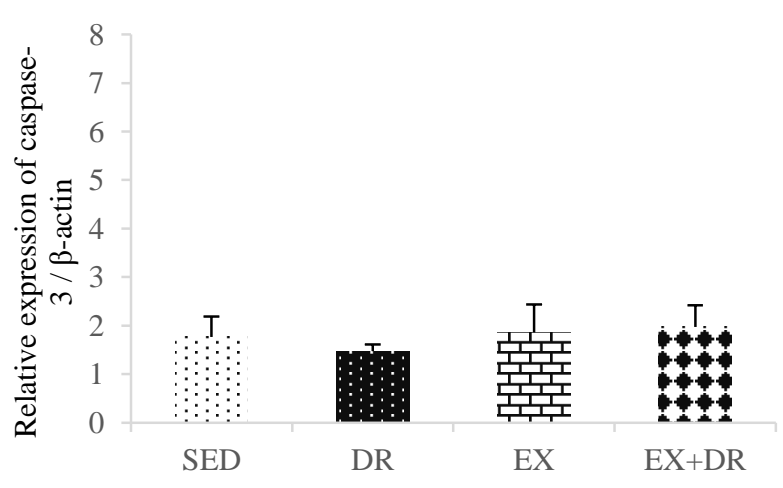

Figure 4. Relative caspase-3 gene expression; SED, sedentary control; DR, dietary restriction; EX, exercise training; EX + DR, exercise training and dietary restriction 
Table 3. Characteristics of rats

\begin{tabular}{lcccc}
\hline & SED $(n=8)$ & DR $(n=8)$ & EX $(n=8)$ & EX + DR $(n=8)$ \\
\hline Initial body weight, g & $322.12 \pm 21.57$ & $314 \pm 22.17$ & $320.09 \pm 19.57$ & $319.34 \pm 20.31$ \\
Final body weight, g & $385.25 \pm 29.6$ & $231 \pm 21.01^{*}$ & $346.22 \pm 22.08^{\neq}$ & $233.5 \pm 27.5^{*}$ \\
Heart, g & $1.06 \pm 0.13$ & $0.69 \pm 0.08^{*}$ & $1.11 \pm 0.16$ & $0.74 \pm 0.11^{*}$ \\
Heart/body weight, $\mathrm{g} \mathrm{kg}^{-1}$ & $2.77 \pm 0.22$ & $2.98 \pm 0.21$ & $3.22 \pm 0.28^{\infty}$ & $3.18 \pm 0.12^{\infty}$ \\
Food intake, $\mathrm{g} \mathrm{d}^{-1}$ & $23 \pm 2$ & $11.5 \pm 1$ & $24 \pm 2$ & $12 \pm 1$ \\
\hline
\end{tabular}

SED, sedentary control; DR, dietary restriction; EX, exercise training; $\mathrm{EX}+\mathrm{DR}$, exercise training and dietary restriction; ${ }^{*} \mathrm{P}<0.05$ against $\mathrm{SED}$ and $\mathrm{EX}$ groups, ${ }^{\neq} \mathrm{P}<$ 0.05 against SED group, ${ }^{\infty} \mathrm{P}<0.05$ against SED and DR groups

\section{Discussion}

In summary, the current findings showed that dietary restriction decreased final body and heart weights. Furthermore, combination of dietary restriction and exercise training prevented severe heart weight loss. Exercise training decreased Bax gene expression and Bax/Bcl-2 ratio; however, these decreases were not seen in dietary restricted groups. No significant interactive effects were reported between the exercise training and dietary restriction. In other words, exercise training was the most important factor. However combination of dietary restriction with exercise training was the most effective factor in increasing $\mathrm{Bcl}-2$ gene expression, dietary restriction and exercise training alone were not effective. No significant changes were observed in caspase- 3 gene expression. These findings showed that dietary restriction resulted in body and heart weight losses. Final body weights were significantly lesser in DR and EX + DR groups than SED and EX groups. These weight losses, which calculated to approximately $26 \%$ of the animal initial weight, were resulted from food restriction and negative energy balance. It is noteworthy that body weights in the two groups of DR and EX + DR were approximately equal while the EX $+\mathrm{DR}$ group was involved in both dietary restriction and exercise training protocols. Preserved body weight in EX + DR group was likely resulted from the maintenance of lean body mass, despite a higher energy expenditure and dietary restriction. In other words, exercise training protected animals from loss of muscle mass during higher energy expenditure and energy deficit (12 weeks of exercise training and food restriction) (18). Although the final body weight increased in EX group (8\%), body weight was lower in EX group than SED group. Results from this study demonstrated that heart weight were higher in EX and EX + DR groups than SED and DR groups, respectively. Moreover, heart to body weight ratio was significantly higher in trained rats than untrained rats. Although several treadmill running studies have failed to show cardiac hypertrophy in rats $(19,20)$, other studies have shown cardiac hypertrophy in mice trained in voluntary running or intensity controlled treadmill running protocols $(21,22)$. Increased heart weight is likely affected by exercise training regimens. However, it is noteworthy that conditioning associated with voluntary running in wheels is difficult to quantify because of a wide variation in running within animals. Kemi et al. showed that graded running intensity majorly increased ventricular mass, compared to that fixed running intensity did (21). In the present study, an exercise protocol with graded intensity and duration was used, which resulted in increases in heart weight and heart to body weight ratio.

The current findings indicated that exercise training decreased Bax gene expression and $\mathrm{Bax} / \mathrm{Bcl}-2$ ratio; however, these decreases were not seen in dietary restricted animals. No significant differences were seen between the exercise training group and exercise training and dietary restriction group. In other words, exercise training was effective in decreasing proapoptotic factors. Previous studies by the authors suggested that a 3-month exercise training was effective in decreasing the cardiac mitochondrial proapoptotic gene (23). The $\mathrm{Bax} / \mathrm{Bcl}-2$ ratio is an indicator of mitochondrial induced apoptotic potential since Bcl2 binds and opposes the pro-apoptotic activity of Bax by preventing Bax conformational change or translocation to mitochondria (9). Fang et al. showed that blocking the mitochondria permeability pore decreased the apoptosis rates after myocardial infarctions (24). Evidence suggest that exercise training can decrease Bax gene expression or the $\mathrm{Bax} / \mathrm{Bcl}-2$ ratio and that hence decrease apoptosis by minimizing mitochondrial permeability. However this mechanism has not fully been described, recent studies by Vainshtein et al. suggest that Bax translocation to mitochondria increases in response to oxidative stress 
(25). This may partially occur due to the activation of cytosolic Jun N-terminal kinases (JNKs), which are phosphorylated in the presence of cellular stressors and subsequently inhibit Bcl-2 expression, allowing Bax translocation to mitochondria. Then, Bax participates in opening of mitochondrial permeability transition pores (mtPTPs), which is immediately followed by the release of pro-apoptotic apoptosis inducing factors (AIFs) and cytochrome $\mathrm{C}$ into the cytosol. In response to training, similar levels of oxidative stress result in lower JNK phosphorylation levels in heart. This is coincided with reduced Bax translocation to mitochondria (25). However, significant differences exist between the acute and chronic changes in these pathways due to the exercise. For example, Arslan et al. showed increased skeletal muscle apoptosis in normal mice within $48 \mathrm{~h}$ of spontaneous acute wheel running (26). In contrast, Li et al. reported that longterm endurance exercises could change the cardiac Bcl-2 and Bax mRNA expressions and induce cardiac apoptosis by the oxidative stress (16). Moreover, Liu et al. suggested that exhaustive training would increase Bax expression and decrease $\mathrm{Bax} / \mathrm{Bcl}-2$ ratio in rat skeletal muscles (27). Differences in intensity or duration of exercise protocols could be responsible for differences in results. These studies indicated that intense and prolonged exercise could facilitate apoptosis due to the increased oxidative stress. In a study by Liu et al. (27), treadmill speed reached $35 \mathrm{~m}$ $\min ^{-1}$ and the actual training duration ranged 180-200 min in Week 7 of training. In the current study, treadmill speed included $33 \mathrm{~m} \mathrm{~min}^{-1}$ and training duration did not exceed 60 min in Week 12.

In the current study, dietary restriction included no significant effects on pro and anti-apoptotic genes. However, combination of dietary restriction with exercise training increased $\mathrm{Bcl}-2$ expression. Contrary to these findings, previous studies indicated that dietary or caloric restriction would increase $\mathrm{Bcl}-2$ expression and decrease Bax expression and $\mathrm{Bax} / \mathrm{Bcl}-$ 2 ratio $(3,13,14)$. Differences in ages and dietary restrictions could be responsible for the differences in results. It seems that modulation of apoptosis often occurs in elderly rats with moderate dietary intakes, but the basic mechanism of the efficacy remains unclear. However, the action mechanisms in various organs are significantly heterogeneous. Niemann et al. reported that caloric restriction would stabilize the mitochondrial respiratory function, decrease reactive oxygen species (ROS) release and pro-apoptotic activation in aged left ventricles; thereby, reducing age associated deterioration of the cardiac function (28). Aging hearts seem to be more susceptible to apoptosis than young hearts. Relatively, dietary restriction exerts an anti-apoptotic action in aging hearts. Rats used in the present study were young and hence results are particularly interesting, considering that young, healthy rodents normally show lower heart apoptosis activities at the baseline. Moreover, a severe dietary restriction (-50\%) was used in this study, while Marzetti et al. suggested that mild caloric restrictions (8-40\%) would reduce age associated cardiomyocyte apoptosis (3). However, based on the results from this study, it is possible that combination of dietary restriction with exercise training affects increase of Bcl-2 expression and decrease of apoptosis. Protective effects of exercise training and dietary restriction are suggested to share common signaling pathways that modulate apoptosis. These may include inflammatory cytokines, oxidative stresses and protective stressresponsive proteins such as the Mn-isoform of superoxide dismutase and IGF-1/Akt pathway. Thus, dietary restriction and exercise training seem to be a synergistic and practical tactic against apoptosis processes. However, the exact benefits of the combination of dietary restriction and exercise training are still unclear and need further investigations. The current findings indicated that exercise training and dietary restriction did not affect caspase-3 gene expression with similar results in all groups. As previously highlighted, it has been suggested that apoptosis increases in tissues with increases in age. This possibly explains no significant changes in caspase-3 gene expression in EX and EX + DR groups in the current study since animals in these groups were only six months of age and changes in caspase levels were too low to be detected (29). Siu et al. found that eight weeks of treadmill training upregulated antiapoptotic markers in muscles of young adult rats. Although these inhibitors acted on caspases, the enzyme activity of caspase- 3 was unchanged after the training (30). However, these results are important because young, healthy rodents usually demonstrate low levels of muscle apoptosis at the baseline. Significant changes in caspase- 3 seem to occur when the basal levels of caspase- 3 are high; such as that seen 
in old (31), obese (9) and sick (4) animals. Kwak et al. suggested that aging hearts would be more susceptible to apoptosis than young hearts and regular exercise trainings would exert anti-apoptotic actions in aging hearts (31). Differences in results were possibly seen due to differences in exercise protocols (voluntary instead of forced), types of exercises (running instead of swimming), durations of exercise exposures (acute instead of chronic) and levels of dietary restrictions (mild instead of severe). However, pro-apoptotic signaling might stimulate protein degradations (32), leading to decreased muscle force generation (33), independent myonuclei removal or cell death. Although basal levels of the myocardial apoptosis are relatively low in young healthy animals, apoptosis in non-dividing cardiac myocytes, even at low rates over many months or years, could be substantial and contribute to myocardial dysfunction or heart failure in older ages $(9,34)$.

\section{Conclusion}

In summary, this study has shown that combination of dietary restriction with exercise training can prevent severe heart weight loss. Exercise training decreases Bax gene expression and $\mathrm{Bax}$ to $\mathrm{Bcl}-2$ ratio and hence combination of dietary restriction with exercise training is the most effective parameter in increasing Bcl-2 gene expression. Furthermore, these findings have demonstrated that exercise training and dietary restriction do not affect caspase-3 gene expression in young healthy rats. However, further studies are necessary to better understand effects of exercise training and dietary restriction on cardiac apoptosis.

\section{Acknowledgement}

The authors would like to thank Dr. Farzam Sheykhzadeh and Dr. Amir Monfaredan for their helps.

\section{Financial disclosure}

The authors declared no financial interest.

\section{Funding/Support}

This research did not receive any specific grant from funding agencies in the public, commercial, or not for-profit sectors.

\section{References}

1. Roth GA, Johnson C, Abajobir A, Abd-Allah F, Abera SF, Abyu G, et al. Global, Regional, and National Burden of Cardiovascular Diseases for 10 Causes, 1990 to 2015. J Am Coll Cardiol. 2017; 70(1): 1-25.
2. Dadson K, Hauck L, Billia F. Molecular mechanisms in cardiomyopathy. Clinical Science. 2017; 131(13):1375-1392.

3. Marzetti E, Wohlgemuth SE, Anton SD, Bernabei R, Carter CS, Leeuwenburgh C. Cellular mechanisms of cardioprotection by calorie restriction: state of the science and future perspectives. Clin Geriatr Med. 2009; 25(4): 715-732.

4. Favaloro B, Allocati N, Graziano V, Ilio C.D, Laurenzi V.D. Role of Apoptosis in disease. Aging. 2012; 4(5):330-349.

5. Lin YY, Hsieh PS, Cheng YJ, Cheng SM, Chen C, Huang CY, et al. Anti-apoptotic and Pro-survival Effects of Food Restriction on High-Fat Diet-Induced Obese Hearts. Cardiovasc Toxicol. 2017; 17:163-174.

6. Wencker D, Chandra M, Nguyen K, Miao W, Garantziotis S, Factor SM, et al. A mechanistic role for cardiac myocyte apoptosis in heart failure. J Clin Invest. 2003; 111:1497-1504.

7. Kwak HB. Effects of aging and exercise training on apoptosis in the heart. J Exerc Rehabil. 2013; 9(2):2129.

8. Ko IG, Kim SE, Kim CJ, Jee YS. Treadmill exercise alleviates aging-induced apoptosis in rat cardiac myocytes. Inter J Gerontology. 2013; 7(3):152-7.

9. Peterson JM, Bryner RW, Sindler A, Frisbee JC, Alway SE. Mitochondrial apoptotic signaling is elevated in cardiac but not skeletal muscle in the obese Zucker rat and is reduced with aerobic exercise. J Appl Physiol. 2008; 105(6):1934-43.

10. Quindry JC, Miller L, McGinnis G, Kliszczewicz B, Irwin JM, Landram M, et al. Ischemia reperfusion injury, KATP channels, and exercise-induced cardioprotection against apoptosis. J Appl Physiol. 2012; 113(3):498506.

11. Marin-Garcia J, Goldenthal MJ. Mitochondrial centrality in heart failure. Heart Fail Rev. 2008; 13(2):137-50.

12. Santana ET, Serra AJ, Silva Junior JA. Aerobic exercise training induces an anti-apoptotic milieu in myocardial tissue. Motriz: Revista de Educacao Fisica. 2014; 20(2):233-238.

13. Walsh M, Shi Y, Remmen HV. The effects of dietary restriction on oxidative stress in rodents. Free Radic Biol Med. 2014; 66: 88-99.

14. Ma L, Wang R, Dong W, Li Y, Xu B, Zhang J. Longterm caloric restriction in mice may prevent age-related learning impairment via suppression of apoptosis. Behavioural Brain Research. 2016; 315: 45-50.

15. Patel BP, Safdar A, Raha S, Tarnopolsky MA, Hamadeh MJ. Caloric restriction shortens lifespan through an increase in lipid peroxidation, inflammation and apoptosis in the G93A mouse, an animal model of ALS. PLoS One. 2010; 5(2):e9386. 
16. Li X, Lu J, Wu W. Effect of Long-term Endurance Exercise on Cardiac Apoptosis. $\mathrm{J}$ of Mian Nor Univ. 2009; 7: 2009-11.

17. Natio H, Powers SK, Demirel HA and Aoki J. Exercise training increases heat shock protein in skeletal muscles of old rats. Med Sci Sports Exerc. 2001; 33(5): 729-734.

18. Swift DL, Johannsen NM, Lavie CJ, Earnest CP, Church TS. The Role of Exercise and Physical Activity in Weight Loss and Maintenance. Prog Cardiovasc Dis. 2014; 56(4):441-447.

19. Fitzsimons DP, Bodell PW, Herrick RE, Baldwin KM. Left ventricular functional capacity in the endurancetrained rodent. J Appl Physiol. 1990; 69(1): 305-312.

20. Schaible TF, Scheuer J. Cardiac function in hypertrophied hearts from chronically exercised female rats. J Appl Physiol. 1981; 50(6): 1140-1145.

21. Kemi OJ, Loennechen JP, Wisloff U, Ellingsen 0. Intensity-controlled treadmill running in mice: cardiac and skeletal muscle hypertrophy. J Appl Physiol. 2002; 93(4): 1301-1309.

22. Allen DL, Harrison BC, Maass A, Bell ML, Byrnes WC, Leinwand LA. Cardiac and skeletal muscle adaptations to voluntary wheel running in the mouse. J Appl Physiol. 2001; 90(5):1900-1908.

23. Jafari A, Pourrazi H, Nikookheslat S, Baradaran B. Effect of exercise training on Bcl-2 and Bax gene expression in the rat heart. Gene Cell Tissue. 2015; 2(4): e32833.

24. Fang J, Wu L, Chen L. Postconditioning attenuates cardiocyte ultrastructure injury and apoptosis by blocking mitochondrial permeability transition in rats. Acta Cardiol. 2008; 63(3): 377-387.

25. Vainshtein A, Kazak L, Hood DA. Effects of endurance training on apoptotic susceptibility in striated muscle. $\mathbf{J}$ Appl Physiol. 2011; 110(6):1638-45.
26. Arslan, S.; Erdem, S.; Sivri, A.; Hascelik, Z.; Tan, E. Exercise-induced apoptosis of rat skeletal muscle and the effect of meloxicam. Rheumatol Int. 2002; 21(4):133136.

27. Liu WY, He W, Li H. Exhaustive training increases uncoupling protein 2 expression and decreases Bcl2/Bax ratio in rat skeletal muscle. Oxid Med Cell Longev. 2013; 2013: 780719.

28. Niemann B, Chen Y, Issa H, Silber RE, Rohrbach S. Caloric restriction delays cardiac ageing in rats: role of mitochondria. Cardio Rese. 2010; 88(2): 267-276.

29. Selman C, Gredilla R, Phaneuf Sh, Kendaiah S, Barja G, Leeuwenburgh $\mathrm{Ch}$. Short-term caloric restriction and regulatory proteins of apoptosis in heart, skeletal muscle and kidney of Fischer 344 rats. Biogerontology. 2003; 4: 141-147.

30. Siu, P. M.; Bryner, R. W.; Murlasits, Z.; Alway, S. E. Response of XIAP, ARC, and FLIP apoptotic suppressors to $8 \mathrm{wk}$ of treadmill running in rat heart and skeletal muscle. J Appl Physiol. 2005; 99(1):204-209.

31. Kwak HB, Song W, Lawler JM. Exercise training attenuates age-induced elevation in Bax/Bcl-2 ratio, apoptosis, and remodeling in the rat heart. FASEB. 2006; 20(6):791-3.

32. Du J, Wang X, Miereles C, Bailey JL, Debigare R, Zheng $B$, et al. Activation of caspase-3 is an initial step triggering accelerated muscle proteolysis in catabolic conditions. J Clin Invest. 2004; 113:115-123.

33. Ruetten H, Badorff C, Ihling C, Zeiher AM, Dimmeler $\mathrm{S}$. Inhibition of caspase-3 improves contractile recovery of stunned myocardium, independent of apoptosisinhibitory effects. J Am Coll Cardiol. 2001; 38: 2063 2070 .

34. Hu A, Jiao X, Gao E, Li Y, Sharifi-Azad S, Grunwald Z, et al. Tonic beta-adrenergic drive provokes proinflammatory and proapoptotic changes in aging mouse heart. Rejuvenation Res. 2008; 11: 215-226. 